\title{
City Prosperity Initiative Index: Using AHP Method to Recalculate the Weights of Dimensions and Sub- Dimensions in Reference to Tehran Metropolis
}

\author{
By Parsa Arbab ${ }^{1}$
}

\begin{abstract}
City Prosperity Initiative (CPI) as a comprehensive multidimensional index agreed globally, is a broad and flexible conceptual framework for measuring and monitoring the urbanization and urbanism as a consequence of this process. This initiative is a fundamental approach for defining an integrative and incremental vision and subsequently multi-sectorial and spatial analysis based direction for its fulfilment towards the sustainability path and sustainable urban development in different hierarchical levels and scales of global, national, regional, and local. The CPI is accompanied by a conceptual matrix, the Wheel of Urban Prosperity, in terms of six key components or dimensions associated with the city and urban settlement, including Productivity, Infrastructure Development, Quality of Life, Equity and Social Inclusion, Environmental Sustainability, and Urban Governance and Legislation. Each of these aspects includes 3 to 5 subdimensions defined and measured by a group of variables or indicators. Thus, the City Prosperity Initiative Index is essential basis to found and promote a new pattern or model of urbanization in the global scale which is adaptive to the contextual conditions and dynamics. Therefore, one of the most key issues in relation to the CPI Index is the weights of the dimensions and sub-dimensions in terms of the conceptualizations of a prosperous city based on the local priorities. Accordingly, this paper has been focused on the City Prosperity Initiative Index and subsequently recalculating the weights of its dimensions and sub-dimensions using Analytic Hierarchy Process (AHP) method according to the contextual situation of Tehran Metropolis in Iran.
\end{abstract}

Keywords: City Prosperity Initiative (CPI) Index, Sustainability, Urban Prosperity, Analytic Hierarchy Process (AHP) Method, Tehran Metropolis

\section{Introduction: Urban Prosperity}

For a prosperous life, the provision of basic material and immaterial needs is crucial. However, the prosperity is more than fulfilling basic needs and accordingly, urban prosperity is more than combating urban problems (Sasaki, 2014, 6). This is why Jackson believes that "prosperity consists in our ability to flourish as human beings within the ecological limits of a finite planet. The challenge for our society is to create the conditions under which this is possible. It is the most urgent task of our times" (Jackson, 2009, 16).

"What makes cities prosperous? The city is a powerful and wonderful construct of history that developed in response to geographical forces that are now well understood, as are the main keys to urban prosperity". The first major key to prosperity is human capital that encompasses knowledge and skills acquired during initial training, experience acquired throughout working life and further training, and economic behavior. The second factor is connectivity defined through the external and internal connectivity that 
their strength derived from the concentration associated with the outer and inner relations in the labor market, between the producers and the users of knowledge. Both internal and external connectivity also depend to a considerable extent on the quality of infrastructure. Another undisputed factor is the propensity for entrepreneurship including complex institutional and cultural phenomena that are decisive factors in the incentive to invest and innovate. Finally, the last factor and most difficult key is the ability to contend with the inherent imbalances in urban development (Prager, 2017, 14).

On this base, urban prosperity could be defined as citizens' opportunities 1-to (re)discover via knowledge and intellectual development through education, 2-to pursue via meaningful and valuable work and recreation, and 3. within ethical and ecological limits (Sasaki, 2014, 3-7).

Accordingly, this paper has focused on the urban prosperity as a key concept encompassing urban development or urbanization from one side and, at the same time, urban life or urbanism in another side. Two main parts have been considered for this purpose:

1- City Prosperity Initiative Index in terms of definition, framework, approach, and factors including dimensions, sub-dimensions, and indicators;

2- Recalculating the weights of the CPI dimensions and sub-dimensions for achieving efficient index based on the contextual situation and local periorities in reference to Tehran Metropolis;

\section{City Prosperity Initiative (CPI)}

In 2012, UN-Habitat created a tool to measure the sustainability of cities. This tool known as the City Prosperity Index that was accompanied by a conceptual matrix, the Wheel of Urban Prosperity in terms of five key components including 1Productivity, 2-Infrastructure Development; 3-Quality of Life; 4-Equity and Social Inclusion, 5-Environmental Sustainability. Governance and Legislation was added to them later as the sixth component. On this base, an equitable prosperous sustainable city was focused as a productive city, a resilient city, a safe and healthy city, an inclusive city, a green city, and a planned city (UN-Habitat, 2013, 7).

Accordingly in 2013, UN- Habitat received numerous requests from local authorities and central governments to estimate their respective prosperity indexes. Mayors and other decision makers wanted to know how their cities feature in comparison with other cities. This included knowledge on how to improve ratings and measurements of cities towards the prosperity path through the plans, policies, and the possible impacts of these actions. Because of these demands, the City Prosperity Index was transformed into a global initiative known as the City Prosperity Initiative (CPI) sets out a framework whereby the relationship between urban prosperity and the factors influencing and, ultimately, influenced by it can be viewed.

This initiative is both a metric index and a policy dialogue, which offers cities from developed and developing countries the possibility to create indicators and baseline information, targets, and goals that can support the definition of ambitious and measurable city-visions and long-term plans. The City Prosperity Initiative (CPI) as a 
global monitoring framework for the urban Sustainable Development Goals (SDGs), is an integral part of the data revolution for sustainable development. It not only aims at the integration of new sources of data and the increase in the usefulness of information, but also enables city authorities, as well as local and national stakeholders, to identify opportunities and potential areas of intervention for their cities to become more prosperous. While there is need for choosing the best and most sustainable options and alternatives, the CPI can play a vital role in this regard (Jones et al. 2015, 20; Stead, 2015, 64; UN-Habitat, 2016a, 4; UN-Habitat, 2016c, 4). Figure1 presents the key capabilities of the City Prosperity Initiative as a metric index and policy dialogue.

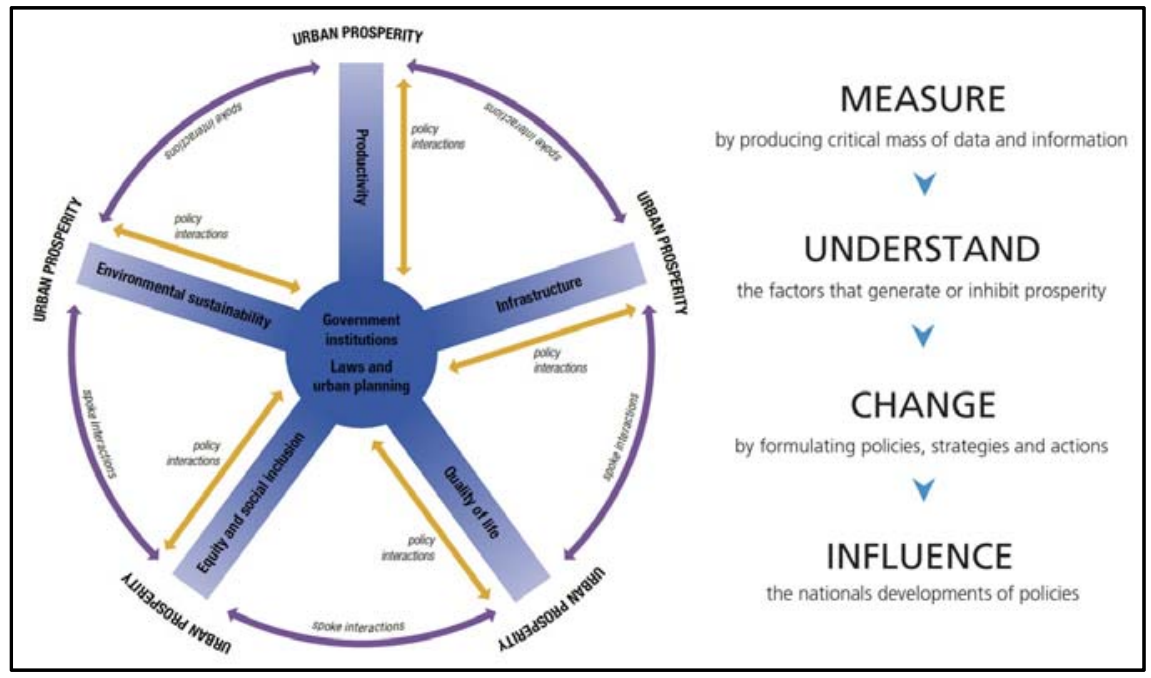

Figure1: City Prosperity Initiative as a Metric Index and Policy Dialogue

(UN-Habitat, 2012 and 2016a)

\section{Distinct and Different Framework of the CPI}

Most indexes have been designed for national governments using country aggregates, many of which are sectorial in nature, focusing on particular dimensions of development (environment, competitiveness, governance, corruption, etc.). The City Prosperity Initiative addresses this gap at the scale of cities, proposing a global, multidimensional tool to test prosperity (i.e., a broad concept including wealth, happiness and health) (Bonaiuto et al. 2015, 53-54). The CPI offers a unique and holistic view of sustainable urban development, articulating the different dimensions of city growth, in four unique ways (UN-Habitat, 2015a, 2, 28; UN-Habitat, 2016a, 5-9):

\subsection{Flexible Monitoring Framework}

The CPI is not a rigid blueprint. The CPI as a living framework takes into account the contextual needs and particularities of cities. Although it promotes a new urbanization model that is universal (cities that are compact, resilient, socially diverse, energy efficient and economically sustainable), it recognizes the need to be adaptable to different city and country circumstances, according to diverse urbanization challenges 
and opportunities. As part of this flexible approach, the CPI has a double function. Firstly, it serves as a platform for global comparability in which cities can assess their situation, compare their rate, and present performance with other cities. Secondly, it acts as a strategic policy tool where the data and information is adapted to local or contextual needs, and used to measure progress and identify deficiencies in the different dimensions of prosperity. Figure 2 presents the incremental approach achieved through the CPI framework.

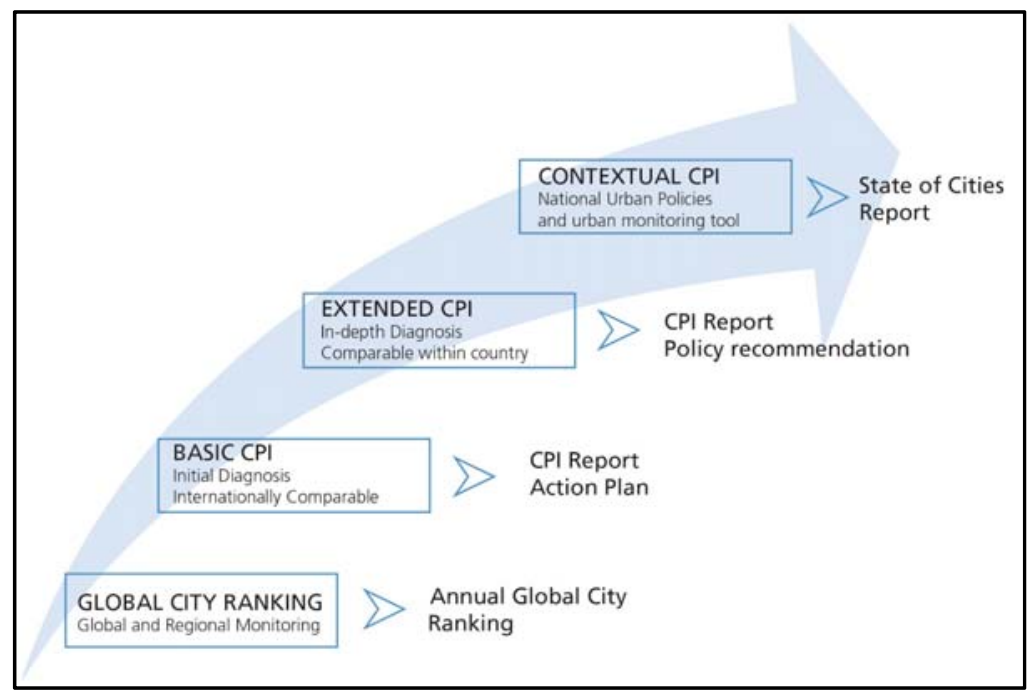

Figure2: Incremental Approach based on the CPI Framework

(UN-Habitat, 2016a)

\subsection{Initiative to Promote the Integration}

In efforts towards improving economic productivity or providing infrastructure, some cities may further exacerbate inequalities or negatively impact on environmental conditions. Conversely, other cities can have unintended results in the quality of life, while implementing specific programmes and policies. The CPI looks at these interactions and measures inter sectorial relationships, and attempts to reinforce them. By conducting policy simulations, the CPI assesses the possible effects of specific policies on the different dimensions of prosperity. On this base, the CPI promotes integration in the implementation of a more sustainable urbanization model in order to address the environmental, social and economic objectives of sustainability. This integration looks at the mutually reinforcing aspects of the different components of the urbanization process.

\subsection{Innovative Tool Based on Spatial Analysis}

The form, planning and structure of the city can conspire against prosperity or act together to boost it. Because of the need to produce accurate, reliable, timely and disaggregated data, UN-Habitat has created an important innovation in the CPI by integrating spatial indicators and analysis in the different dimensions of prosperity. When 
spatial indicators are combined with socio economic indicators disaggregated at intra-city level, they can address transformations in the cities with reinvigorated urban planning and design, adequate laws and institutions and local economic development solutions. On this base, the CPI structure provides a wealth of new analytical tools based on the spatial indicators. New indicators such as street connectivity, public space, agglomeration economies provide clear spatial distributions that help increase value judgment and support decision- making.

\subsection{Multi-Scale Decision-Making Tool}

The CPI's objective is to support decision-making for multi-scale and various territorial levels of government ranging from national urban policies to regional and metropolitan strategies; and city-wide interventions to sub-city districts or neighborhoods. Figure3 shows these multi scales or levels of decision-making based on the City Prosperity Initiative framework. The CPI gives decision-makers the ability to make adequate and evidence based decisions from a territorial perspective, thus articulating different tiers of government and sectorial interventions in urban areas. Except a global scale, the CPI supports the development and implementation of integrated national urban policies in some cases. In other cases, the CPI provides information at the regional and metropolitan levels through building linkages between municipal governments and articulating responses that contemplate regional development and better integration of sectors. Overall, the CPI produces information at city level, and when data allows, at sub-city level. This information is critical to support local decision-making in key priority areas of development.

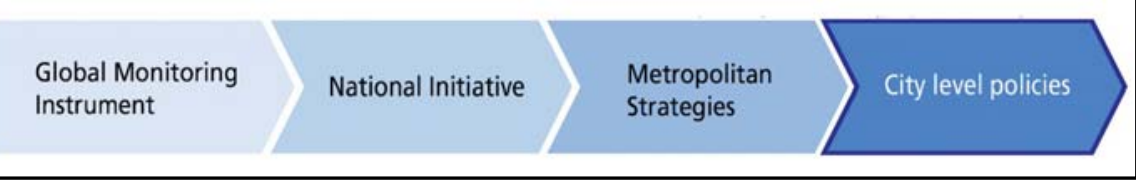

Figure 3: Multi Scales Decision-Making by the CPI Framework

(UN-Habitat, 2015a)

\section{Integrative Three Legged Approach of the CPI}

The CPI considers that urbanization, as a process, should adhere to human rights principles, while the city, as an outcome, should meet specific human rights standards that need to be measured. The CPI promotes integration in the implementation of a more sustainable urbanization model, in order to address the environmental, social and economic objectives of the sustainability. This integration looks at the mutually reinforcing aspects of the different components of the urbanization process. On this base, the CPI proposes a limited number of key transformational interventions, which are designed using the essence of the New Urban Agenda main components, UN-Habitat's three-legged approach which incorporates planning and design, legislation and regulation, and economy and finance. This approach is a policy formulation framework that avoids that action plans and strategic solutions follow a sectorial approach. As Figure4 shows, the CPI connects these three strategic 
interventions in a way that maximizes benefits and possible impacts in terms of the sustainable solutions (UN-Habitat, 2015a, 29; UN-Habitat, 2015b, 19; UN-Habitat, 2016a, 10):

\subsection{Planning and Urban Design}

A reinvigorated planning involves political choices and commitments, which must be turned into tools and sustainable technical solutions. The City Prosperity Initiative identifies a number of these interventions that can help cities to move on the prosperity path, such as plan infill development and guided city expansions, multimodal mobility development strategies, neighborhood planning for enhanced social diversity and mixed-land uses, etc.

\subsection{Urban Legislation and Governance}

Laws and institutions provide the normative and organizational underpinnings of urban change and the power and rigor for enabling action, granting authority, defining relations and generally sustaining continuity or triggering change. The City Prosperity Initiative identifies transformative actions in areas such as the reform of urban legal systems, regulations on urban planning, building regulations and zoning laws, and participatory and inclusive land readjustments.

\subsection{Urban Economy and Municipal Finance}

The City Prosperity Initiative identifies transformative actions that can help local and national governments develop revenue enhancement plans which can leverage innovative tools and simple, transparent revenue collection mechanisms. These mechanisms can harness and support growth while garnering community buy-in for public sector revenue collection efforts.

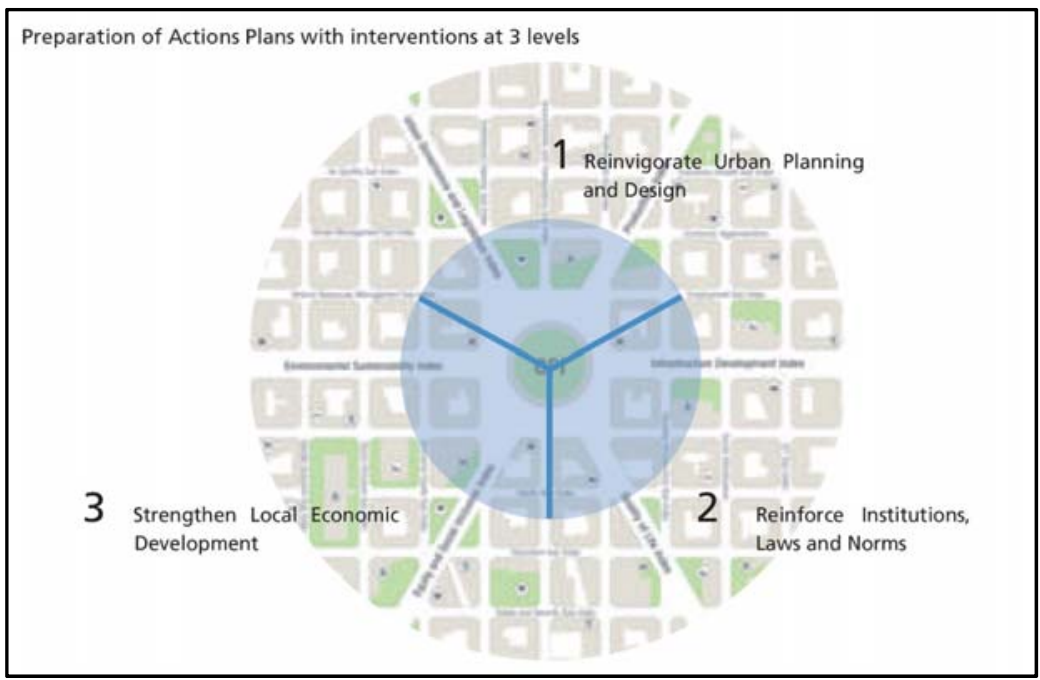

Figure4: CPI Based on the Three-Legged Approach of the New Urban Agenda

(UN-Habitat, 2016a) 


\section{Dimensions, Sub-Dimensions, and Indicators of the CPI}

Sustainable development as a new paradigm, presents a significant milestone and sets out a new development agenda and framework for socio-economic and environmental sustainability of humanity (Akotia, Opoku, and Hafiz, 2017, 148). Therefore, the CPI argues for the need to move towards measuring the broad conception of human and societal well-being in terms of the sustainability. On this base, prosperity or success of the city, in other words, requires these essential qualities (Wong, 2015, 4; UN-Habitat, 2015a, 3):

$\checkmark$ Productivity: A prosperous city contributes to economic growth and development. Productivity includes generating income, employment and equal opportunities that further provide adequate living standards for the entire population;

$\checkmark$ Infrastructure Development: A prosperous city deploys infrastructure, physical assets, and amenities. Infrastructure Development includes adequate water, sanitation, power supply, road network, information and communications technology, etc. required to sustain both the population and the economy, and provide better quality of life;

$\checkmark$ Quality of Life: A prosperous city provides social services for improved living standards and guarantees safety and security, education, health, and recreation required for improved living standards, enabling the population to maximize individual potential and to lead fulfilling lives.

$\checkmark$ Equity and Social Inclusion: A prosperous city ensures equitable distribution of wealth and benefits and eradicates poverty and inequalities. No city can claim to be prosperous when large segments of the population live in abject poverty and deprivation. This involves reducing the incidence of slums and new forms of poverty and marginalization.

$\checkmark$ Environmental Sustainability: A prosperous city protects the urban environment and preserves natural assets while creating wealth. Well-planned cities do not destroy or degrade the environment and in opposite, promote environmental sustainability.

Moreover, Governance and Legislation as the sixth quality or dimension has been added to the mentioned set that is described below:

$\checkmark$ Governance and Legislation: A prosperous city combines sustainability and shared prosperity through effective urban governance and transformational leadership, deploying appropriate and effective policies, laws and regulations, and creating adequate institutional frameworks with strong local institutions and sound institutional arrangements.

Hence, The City Prosperity Initiative (CPI) is a multidimensional index. The prosperity of a city is determined based on a collection of factors or dimensions that are related to conceptualizations of a prosperous city. Each dimension is composed of subdimensions, which are defined from a group of variables or indicators that are measured for each city. When sub-dimensions are made-up by two or more indicators, they are aggregated into one single value. Indicators are standardized using internationallyobserved benchmark. A clear definition of each indicator is presented in the "Measurement of City Prosperity: Methodology and Metadata" (UN-Habitat, 2016a, 67). Figure 5 and Table1 present the sub-dimensions and indicators of the City Prosperity Initiative Index. Accordingly, this multidimensional index has 22 sub-dimensions and 62 indicators in terms of conceptualizations of a prosperous city. 


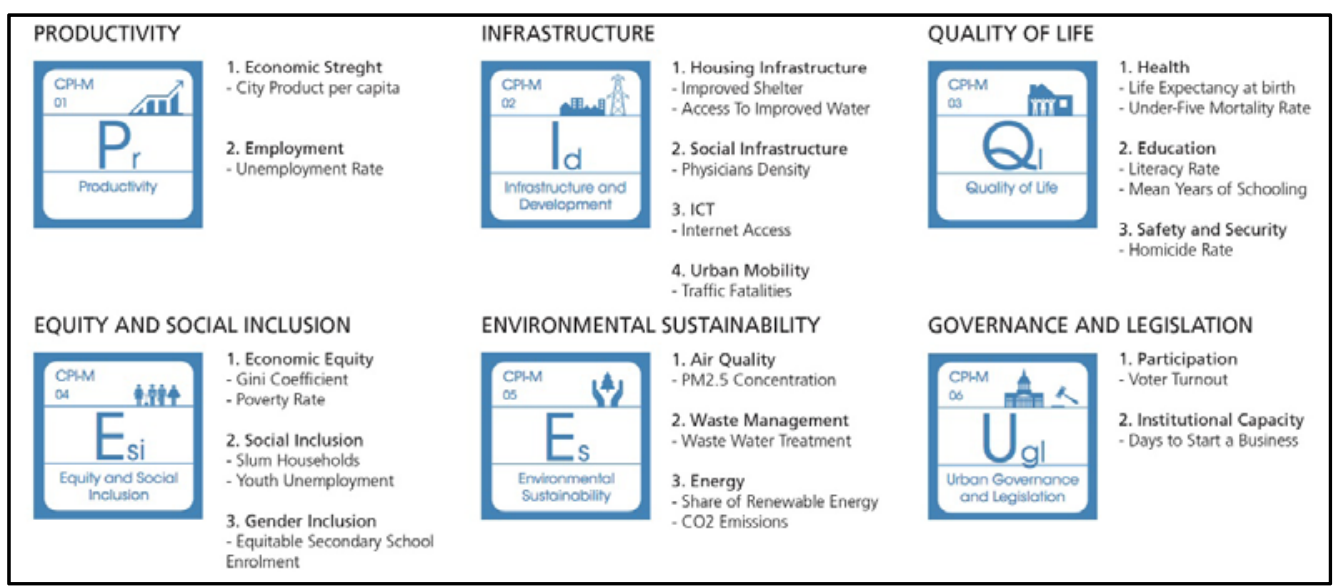

Figure 5: Dimensions and Main Sub-Dimensions of the CPI index

(UN-Habitat, 2015a)

Table1: Indicators of the Dimensions and Sub-Dimensions of the CPI index

\begin{tabular}{|c|c|c|c|c|c|}
\hline Dimension & Sub-Dimension & Indicator & Dimension & Sub-Dimension & Indicator \\
\hline \multirow{5}{*}{ 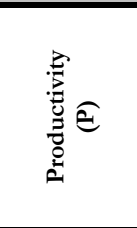 } & $\begin{array}{l}\text { 1. Economic } \\
\text { Strength (EG) }\end{array}$ & \begin{tabular}{|l|}
1.1 City Product per capita \\
1.2 Old Age Dependency Ratio \\
1.3 Mean Household Income \\
\end{tabular} & \multirow{5}{*}{ 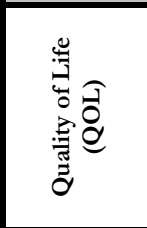 } & \multirow[t]{2}{*}{ 2. Education (E) } & \begin{tabular}{|l|} 
2.1 Literacy Rate \\
2.2 Mean years of Schooling \\
2.3 Early Childhood Education \\
\end{tabular} \\
\hline & \multirow{2}{*}{$\begin{array}{l}\text { 2. Economic } \\
\text { Agglomeration } \\
\text { (EA) }\end{array}$} & 2.1 Economic Density & & & $\begin{array}{l}2.4 \text { Net enrollment rate in higher } \\
\text { education }\end{array}$ \\
\hline & & \multirow{2}{*}{$\begin{array}{l}\text {..2 Economic Speciallzation } \\
3.1 \text { Unemployment Rate }\end{array}$} & & \multirow{2}{*}{$\begin{array}{l}\text { 3. Safety and } \\
\text { Security (SS) }\end{array}$} & 3.1 Homicide rate \\
\hline & \multirow[b]{2}{*}{ 3. Employment (E) } & & & & 3.2 Theft rate \\
\hline & & \begin{tabular}{|l|}
$\begin{array}{l}3.2 \\
\text { Ratio }\end{array}$ \\
3.3 Informal Employment
\end{tabular} & & 4. Public Space (PS) & $\begin{array}{l}\begin{array}{l}\text { 4.1 Accessibility to Open Public } \\
\text { Areas }\end{array} \\
\text { 4.2 Green Area per Capita }\end{array}$ \\
\hline \multirow{15}{*}{ 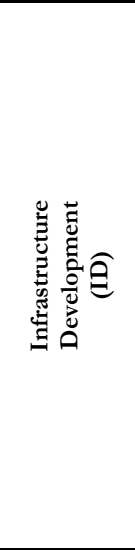 } & \multirow{6}{*}{$\begin{array}{l}\text { 1. Housing } \\
\text { Infrastructure (HI) }\end{array}$} & 1.1 Improved Shelter & \multirow{7}{*}{ 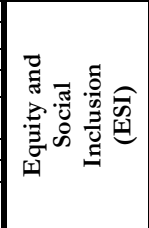 } & \multirow{4}{*}{$\begin{array}{l}\text { 1. Economic Equity } \\
\text { (EE) } \\
\text { 2. Social Inclusion } \\
\text { (SI) } \\
\end{array}$} & 1.1 Gini Coefficient \\
\hline & & 1.2 Access to Improved Water & & & 1.2 Poverty Rate \\
\hline & & 1.3 Access to Improved Sanitation & & & 2.1 Slums Households \\
\hline & & \begin{tabular}{|l}
1.4 Access to Electricity \\
\end{tabular} & & & 2.2 Youth Unemployment \\
\hline & & 1.5 Sufficient Living Area & & on & $\begin{array}{l}3.1 \text { Equitable Secondary School } \\
\text { Enrollment }\end{array}$ \\
\hline & & \begin{tabular}{|l|}
1.6 Population Density \\
2.1 Physician Density
\end{tabular} & & $(\mathrm{GI})$ & \begin{tabular}{|l}
3.2 Women in Local Government \\
3.3 Women in Local Work Force
\end{tabular} \\
\hline & $\begin{array}{l}\text { 2. Social } \\
\text { Infrastructure (SI) }\end{array}$ & 2.2 Number of Public Libraries & & $\begin{array}{l}\text { 4. Urban Diversity } \\
\text { (UD) }\end{array}$ & 4.1 Land Use Mix \\
\hline & $\begin{array}{l}\text { 3. Information and } \\
\text { Communication }\end{array}$ & \begin{tabular}{|l}
3.1 Internet Access \\
3.2 Home Computer Access \\
\end{tabular} & & 1 Air $O u$ lity (AO) & \begin{tabular}{|l|}
1.1 Number of monitoring stations \\
1.2 PM2.5 Concentration \\
\end{tabular} \\
\hline & $\begin{array}{l}\text { Technology } \\
\text { (ICT) }\end{array}$ & 3.3 Average Broadband Speed & 0 & 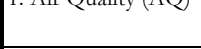 & 1.3 $\mathrm{CO} 2$ Emissions \\
\hline & & \begin{tabular}{|l|}
4.1 Use of Public Transport \\
4.2 Average Daily Travel Time \\
\end{tabular} & 嫣 & 2. W & \begin{tabular}{|l|}
2.1 Solid Waste Collection \\
2.2 Waste Water Treatment \\
\end{tabular} \\
\hline & Mobility & $\begin{array}{l}\begin{array}{l}4.3 \text { Length of Mass Transport } \\
\text { Network }\end{array} \\
\end{array}$ & 表 & VM) & 2.3 Solid Waste Recycling Share \\
\hline & & 4.4 Traffic Fatalities & & $\begin{array}{l}\text { 3. Suitable Energy } \\
\text { (SE) }\end{array}$ & 3.1 Share of Renewable Energy \\
\hline & & 4.5 Affordability of Transport & & & 1.1 Voter Turnout \\
\hline & 5. & \begin{tabular}{|l|}
5.1 Street Intersection Density \\
5.2 Street Density \\
\end{tabular} & & 1. Participation $(\mathrm{P})$ & \begin{tabular}{|l|}
1.2 Access to Public Information \\
1.3 Civic Participation
\end{tabular} \\
\hline & & 5.3 Land Allocated to Streets & $\tilde{\sigma}$ & 2. Muni & 2.1 Own Revenue Collection \\
\hline & & 1.1 Life Expectancy at Birth & & Financing and & 2.2 Days to Start a Business \\
\hline & & \begin{tabular}{|l}
1.2 Under-Five Mortality Rate \\
\end{tabular} & 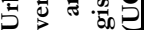 & Instit & 2.3 Subnational Debt \\
\hline$=$ & 1. Health $(\mathrm{H})$ & 1.3 Vaccination Coverage & (2) & Capacity (MFIC) & 2.4 Local Expenditure Efficiency \\
\hline & & 1.4 Maternal Mortality & & $\begin{array}{l}\text { 3. Governance of } \\
\text { Urbanization }(\mathrm{GU})\end{array}$ & 3.1 Land Use Efficiency \\
\hline
\end{tabular}

(UN-Habitat, 2016b)

\section{Recalculation of the CPI Dimensions and Sub-Dimensions Weights}

According to the methodology and metadata of the City Prosperity Initiative Index, dimensions have equal weight in the index, sub-dimensions have equal weight 
within dimensions and indicators have equal weight within sub-dimensions (UN-Habitat, $2016 \mathrm{~b}, 14)$. On this base, importance of the dimensions, sub-dimensions and indicators is considered based on a simple arithmetic average in reference to the number of items. Hence, this multidimensional index is suitable at a general level, to conduct global or regional studies for comparison of countries. Accordingly, it is so essential that the components of the CPI Index to be reviewed in terms of the preference or weight. Contextual situation and local priorities in reference to the facilities and limitations must be taken into account in this regard. For this purpose, dimensions and sub-dimensions of the City Prosperity Initiative Index have been focused for recalculation of their weights based on the Tehran Metropolis situation.

This review have been done through the logic of Analytical Hierarchy Process (AHP) by using of the Expert Choice 11.1 software. On this base, all dimensions and subdimensions have been compared pairwise according to the Saaty Scale, provided in Table2. Moreover, weighting of each item has been done by the professors of the University of Tehran in the fields of regional planning, urban planning, urban management, and urban design. Seven separate matrices have been found respectively for 6 dimensions and 22 sub-dimensions including sub-dimensions of Productivity, subdimensions of Infrastructure Development, sub-dimensions of Quality of Life, subdimensions of Equity and Social Inclusion, sub-dimensions of Environmental Sustainability, and sub-dimensions of Urban Governance and Legislation. Figure6 presents the results of the mentioned comparisons. The values in each matrix have been calculated by geometric mean of different amounts assigned by the experts. The Inconsistency Ratio was been below $0.1(10 \%)$ in all cases that reflects the high logical consistency in the judgments which have provided pretty coherent set of assessments.

Table2: Saaty Scale of Relative Preference for Pairwise Comparison

\begin{tabular}{|c|l|l|}
\hline $\begin{array}{l}\text { Intensity of } \\
\text { Importance }\end{array}$ & Definition & Explanation \\
\hline 1 & Equal Importance & Two activities contribute equally to the objective \\
\hline 2 & Weak or slight & - \\
\hline 3 & Moderate importance & Experience and judgment slightly favor one activity over another \\
\hline 4 & Moderate plus & - \\
\hline 5 & Strong importance & Experience and judgment strongly favor one activity over another \\
\hline 6 & Strong plus & - \\
\hline 8 & $\begin{array}{l}\text { Very strong or demonstrated } \\
\text { importance }\end{array}$ & $\begin{array}{l}\text { An activity is favored very strongly over another; its dominance } \\
\text { demonstrated in practice }\end{array}$ \\
\hline 9 & Very, very strong & - \\
\hline & Extreme importance & $\begin{array}{l}\text { The evidence favoring one activity over another is of the highest } \\
\text { possible order of affirmation }\end{array}$ \\
\hline
\end{tabular}

(Saaty, 2008, 86)

Results show different weights in terms of the importance or preference between the dimensions and sub-dimensions of the City Prosperity Initiative Index. As Table3 and Figure 7 show, the dimensions in the index, in order of importance, are Environmental Sustainability, Infrastructure Development, Equity and Social Inclusion, Quality of Life, Productivity, and Urban Governance and Legislation, respectively with weights of 0.310 , $0.198,0.156,0.155,0.101$, and 0.080 . However, in general, all these factors are equally weighted 0.167. Accordingly weights of the sub-dimensions within each dimension have been recalculated. For example, sub-dimensions of the Infrastructure Development, in 
order of preference, are Housing Infrastructure, Urban Mobility, Social Infrastructure, Information and Communication Technology, and Urban Form, respectively with weights of $0.408,0.220,0.208,0.096$, and 0.068 . By the same process, the final weights of all 22 sub-dimensions of the CPI Index have been recalculated.

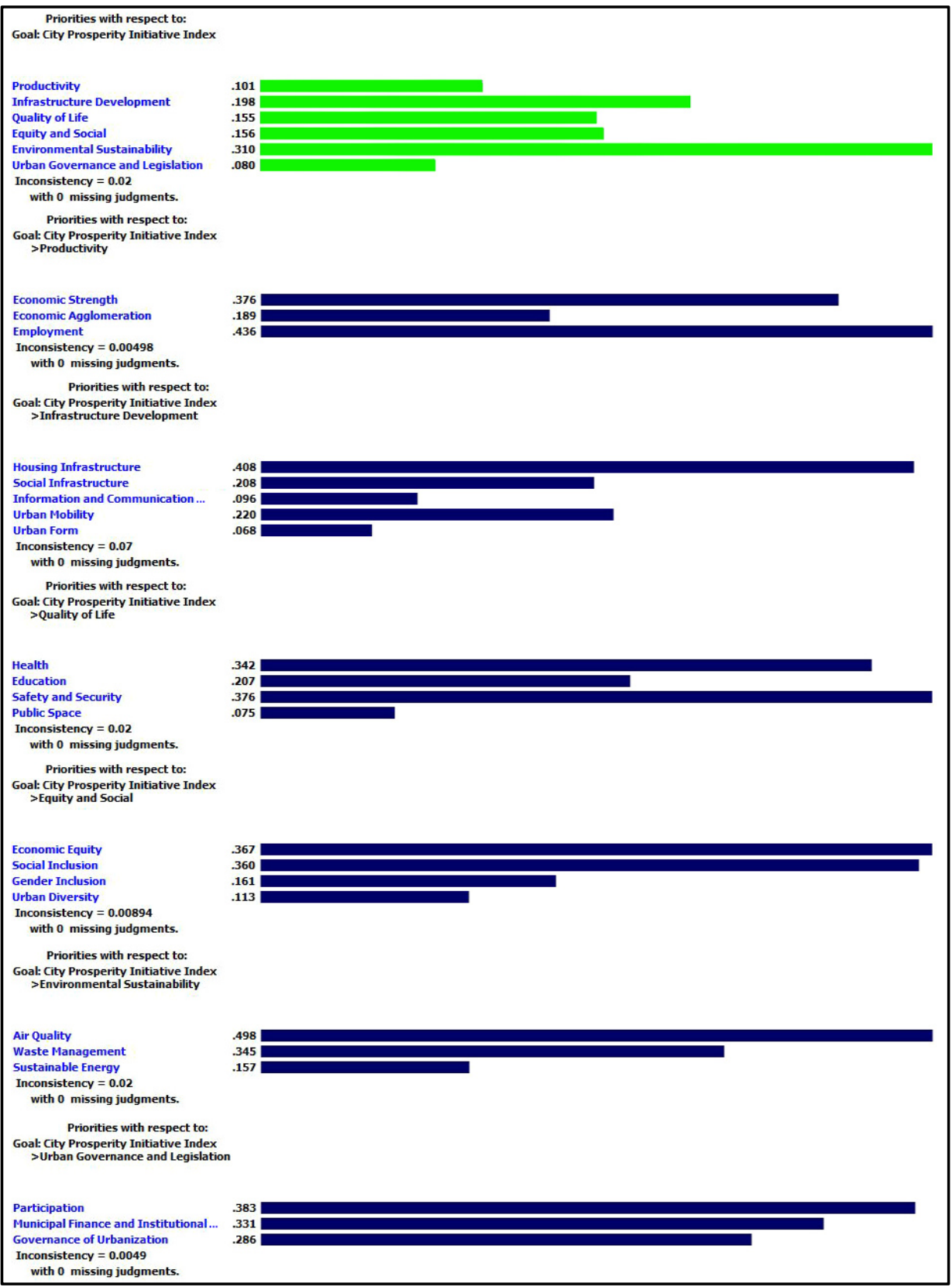

Figure6: Experts Weighting Results by AHP and Expert Choice 
Table3: CPI Dimensions and Sub-Dimensions Weights

\begin{tabular}{|c|c|c|c|c|c|c|c|c|c|}
\hline \multicolumn{5}{|c|}{ This Research (Recalculated) } & \multicolumn{5}{|c|}{ UN-Habitat (UN-Habitat. 2016b) } \\
\hline 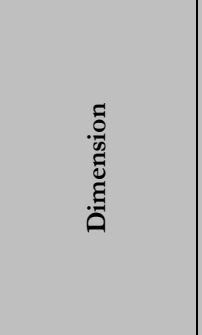 & 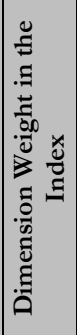 & 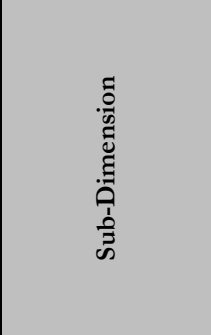 & 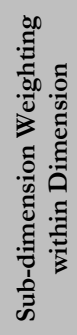 & 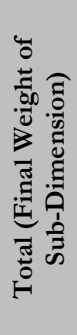 & 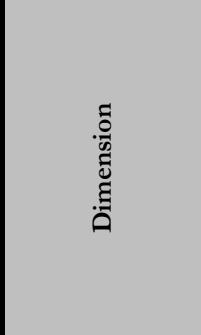 & 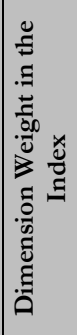 & 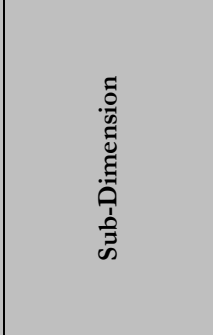 & 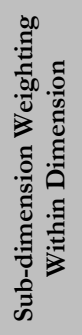 & 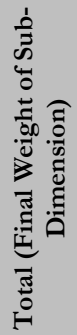 \\
\hline \multirow{3}{*}{ Productivity $(\mathbf{P})$} & \multirow{3}{*}{0.101} & $\begin{array}{c}\text { Economic } \\
\text { Strength (ES) }\end{array}$ & 0.376 & 0.038 & \multirow{3}{*}{ Productivity (P) } & \multirow{3}{*}{0.167} & $\begin{array}{c}\text { Economic } \\
\text { Strength (ES) }\end{array}$ & 0.333 & 0.056 \\
\hline & & $\begin{array}{c}\text { Economic } \\
\text { Agglomeration } \\
\text { (EA) }\end{array}$ & 0.189 & 0.019 & & & $\begin{array}{c}\text { Economic } \\
\text { Agglomeration } \\
\text { (EA) }\end{array}$ & 0.333 & 0.056 \\
\hline & & Employment (E) & 0.436 & 0.044 & & & Employment (E) & 0.333 & 0.056 \\
\hline \multirow{5}{*}{$\begin{array}{c}\text { Infrastructure } \\
\text { Development } \\
\text { (ID) }\end{array}$} & \multirow{5}{*}{0.198} & $\begin{array}{c}\text { Housing } \\
\text { Infrastructure } \\
(\mathrm{HI})\end{array}$ & 0.408 & 0.081 & \multirow{5}{*}{$\begin{array}{l}\text { Infrastructure } \\
\text { Development } \\
\text { (ID) }\end{array}$} & \multirow{5}{*}{0.167} & $\begin{array}{c}\text { Housing } \\
\text { Infrastructure } \\
(\mathrm{HI})\end{array}$ & 0.2 & 0.033 \\
\hline & & \begin{tabular}{|c|} 
Social \\
Infrastructure (SI) \\
\end{tabular} & 0.208 & 0.041 & & & \begin{tabular}{|c|} 
Social \\
Infrastructure $(\mathrm{SI})$ \\
\end{tabular} & 0.2 & 0.033 \\
\hline & & $\begin{array}{l}\text { Information and } \\
\text { Communication } \\
\text { Technology (ICT) }\end{array}$ & 0.096 & 0.019 & & & $\begin{array}{l}\text { Information and } \\
\text { Communication } \\
\text { Technology (ICT) }\end{array}$ & 0.2 & 0.033 \\
\hline & & $\begin{array}{c}\text { Urban Mobility } \\
\text { (UM) }\end{array}$ & 0.220 & 0.044 & & & $\begin{array}{c}\text { Urban Mobility } \\
\text { (UM) }\end{array}$ & 0.2 & 0.033 \\
\hline & & Urban Form (UF) & 0.068 & 0.013 & & & Urban Form (UF) & 0.2 & 0.033 \\
\hline \multirow{4}{*}{$\begin{array}{c}\text { Quality of Life } \\
\text { (QOL) }\end{array}$} & \multirow{4}{*}{0.155} & Health $(\mathrm{H})$ & 0.342 & 0.053 & \multirow{4}{*}{$\begin{array}{l}\text { Quality of Life } \\
\text { (QOL) }\end{array}$} & \multirow{4}{*}{0.167} & Health $(\mathrm{H})$ & 0.25 & 0.042 \\
\hline & & Education (E) & 0.207 & 0.032 & & & Education $(\mathrm{E})$ & 0.25 & 0.042 \\
\hline & & $\begin{array}{c}\text { Safety and } \\
\text { Security (SS) }\end{array}$ & 0.376 & 0.058 & & & $\begin{array}{c}\text { Safety and } \\
\text { Security (SS) }\end{array}$ & 0.25 & 0.042 \\
\hline & & Public Space (PS) & 0.075 & 0.012 & & & Public Space (PS) & 0.25 & 0.042 \\
\hline \multirow{4}{*}{$\begin{array}{c}\text { Equity and } \\
\text { Social Inclusion } \\
\text { (ESI) }\end{array}$} & \multirow{4}{*}{0.156} & \begin{tabular}{|c|} 
Economic Equity \\
(EE)
\end{tabular} & 0.367 & 0.057 & \multirow{4}{*}{$\begin{array}{c}\text { Equity and } \\
\text { Social Inclusion } \\
\text { (ESI) }\end{array}$} & \multirow{4}{*}{0.167} & \begin{tabular}{|c|} 
Economic Equity \\
(EE)
\end{tabular} & 0.25 & 0.042 \\
\hline & & $\begin{array}{c}\text { Social Inclusion } \\
(\mathrm{SI})\end{array}$ & 0.360 & 0.056 & & & $\begin{array}{c}\text { Social Inclusion } \\
(\mathrm{SI})\end{array}$ & 0.25 & 0.042 \\
\hline & & \begin{tabular}{|c|} 
Gender Inclusion \\
(GI)
\end{tabular} & 0.161 & 0.025 & & & \begin{tabular}{|c|} 
Gender Inclusion \\
$(\mathrm{GI})$
\end{tabular} & 0.25 & 0.042 \\
\hline & & $\begin{array}{l}\text { Urban Diversity } \\
\text { (UD) }\end{array}$ & 0.113 & 0.018 & & & $\begin{array}{c}\text { Urban Diversity } \\
\text { (UD) }\end{array}$ & 0.25 & 0.042 \\
\hline \multirow{3}{*}{$\begin{array}{c}\text { Environmental } \\
\text { Sustainability } \\
\text { (ES) }\end{array}$} & \multirow{3}{*}{0.310} & \begin{tabular}{|l|} 
Air Quality (AQ) \\
\end{tabular} & 0.498 & 0.154 & \multirow{3}{*}{$\begin{array}{l}\text { Environmental } \\
\text { Sustainability } \\
\text { (ES) }\end{array}$} & \multirow{3}{*}{0.167} & \begin{tabular}{|l|} 
Air Quality (AQ) \\
\end{tabular} & 0.333 & 0.056 \\
\hline & & $\begin{array}{c}\text { Waste } \\
\text { Management } \\
\text { (WM) }\end{array}$ & 0.345 & 0.107 & & & $\begin{array}{c}\text { Waste } \\
\text { Management } \\
\text { (WM) }\end{array}$ & 0.333 & 0.056 \\
\hline & & $\begin{array}{c}\text { Sustainable } \\
\text { Energy (SE) }\end{array}$ & 0.157 & 0.049 & & & $\begin{array}{c}\text { Sustainable } \\
\text { Energy (SE) }\end{array}$ & 0.333 & 0.056 \\
\hline \multirow{3}{*}{$\begin{array}{c}\text { Urban } \\
\text { Governance and } \\
\text { Legislation } \\
\text { (UGL) }\end{array}$} & \multirow{3}{*}{0.080} & Participation $(\mathrm{P})$ & 0.383 & 0.031 & \multirow{3}{*}{$\begin{array}{c}\text { Urban } \\
\text { Governance and } \\
\text { Legislation } \\
\text { (UGL) }\end{array}$} & \multirow{3}{*}{0.167} & Participation $(\mathrm{P})$ & 0.333 & 0.056 \\
\hline & & $\begin{array}{l}\text { Municipal Finance } \\
\text { and Institutional } \\
\text { Capacity (MFIC) }\end{array}$ & 0.331 & 0.026 & & & $\begin{array}{l}\text { Municipal Finance } \\
\text { and Institutional } \\
\text { Capacity (MFIC) }\end{array}$ & 0.333 & 0.056 \\
\hline & & $\begin{array}{c}\text { Governance of } \\
\text { Urbanization } \\
(G U)\end{array}$ & 0.286 & 0.023 & & & $\begin{array}{c}\text { Governance of } \\
\text { Urbanization } \\
(G U)\end{array}$ & 0.333 & 0.056 \\
\hline Total & 1.00 & - & - & & Total & 1.00 & - & - & 1.00 \\
\hline
\end{tabular}




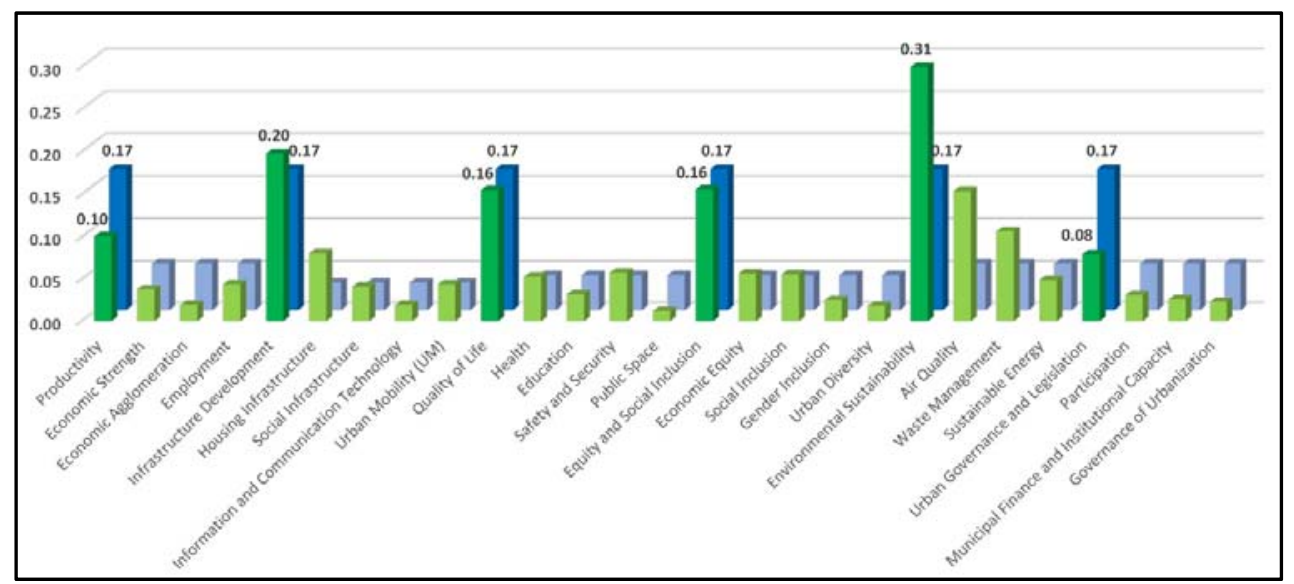

Figure 7: Weights of Dimensions and Final Weights of Sub-Dimensions in the CPI Index

\section{Discussion and Conclusion}

City Prosperity Initiative Index is a broad and flexible conceptual framework for measuring and monitoring the urbanization and urbanism as a consequence of this process. This initiative is a fundamental approach for defining an integrative and incremental vision and subsequently multi-sectorial and spatial analysis based direction for its fulfilment towards the sustainability path and sustainable urban development in different hierarchical levels and scales of global, national, regional, and local. On this base, the prosperity of a city is determined based on a collection of factors or dimensions that are composed of sub-dimensions, which are defined from a group of variables or indicators. Productivity in terms of the economic growth and development for the entire population, Infrastructure Development as the physical assets, amenities and technologies, Quality of Life in terms of the living standards associated with the safety and security, education, health, and recreation, Equity and Social Inclusion as the poverty and inequalities eradication and equitable distribution of the wealth and benefits, Environmental Sustainability in terms of protection and preservation of the urban environment and natural assets, and finally Urban Governance and Legislation as the adequate and transformational institutional arrangements are 6 dimensions of the CPI Index. Accordingly, there are 22 sub-dimensions and 62 indicators within these main components.

The City Prosperity Initiative Index as a basis to found and promote a new pattern or model of urbanization in the global scale, is adaptive to the contextual conditions and dynamics. Therefore, one of the most key issues in relation to the CPI Index is the weights of the dimensions and sub-dimensions in terms of the conceptualizations of a prosperous city based on the local priorities. Accordingly, recalculating the weights of dimensions and sub-dimensions was focused using Analytic Hierarchy Process (AHP) method according to the contextual situation of Tehran Metropolis. The results indicate different importance and preference between the dimensions and sub-dimensions instead of the equal weight in the original model. According to the output of this study, the urban prosperity could be conceptualized for Tehran especially in comparison to the 
other metropolis of Iran such as Mashhad, Isfahan, Karaj, Shiraz, Tabriz, Ahvaz, Qom, Kermanshah, Urmia, Rasht, Zahedan, Kerman, Arak, and Hamadan. Moreover, in addition to the comparative analysis by the general framework of the CPI Index, a more realistic assessment in reference to the other metropolis in the world could be provided by this new framework in terms of recalculated weights of dimensions and subdimensions based on the locality. Further specific studies on this issue can be addressed in the future researches in order to achieve and clarify the supplementary theoretical and empirical findings.

\section{References}

Akotia, Julius, Alex Opoku, and Farahat Hafiz. 2017. "The Extent of Practitioners' Involvement in the Delivery of Sustainable Urban Regeneration Projects in UK." European Journal of Sustainable Development (2017), 6, 2, 147-164

Bonaiuto, Marino, Ferdinando Fornara, Silvia Ariccio, Uberta Ganucci Cancellieri, and Leila Rahimi. 2015. "Perceived Residential Environment Quality Indicators (PREQIs) relevance for UN-HABITAT City Prosperity Index" Habitat International 45: 53-63.

Jackson, Tim. 2009. Prosperity without Growth: Economics for a Finite Planet. London: Earthscan.

Jones, Steven, Moses Tefe, Seth Appiah-Opoku. 2015. "Incorporating stakeholder input into transport project selection - A step towards urban prosperity in developing countries?" Habitat International 45: 20-28.

Prager, Jean-Claude. 2017. "Value Creation and Urban Prosperity." Inventing Tomorrow's Cities Website, February 22. http://.lafabriquedelacite.com.

Saaty, Thomas L. 2008. "Decision making with the analytic hierarchy process." International Journal of Services Sciences 1(1), 83-98.

Sasaki, Ryuei. 2014. "Urban Prosperity without Growth? Sustainable City Development with Focus on Human Flourishing." M.Sc. Thesis of Environmental Studies and Sustainability Science, Lund University.

Stead, Dominic. 2015. "What does the Quality of Governance Imply for Urban Prosperity?" Habitat International 45: 64-69.

UN-Habitat. 2012. State of the World's Cities Report 2012/2013: Prosperity of Cities. United Nations Human Settlements Programme (UNHSP).

UN-Habitat. 2013. Cities Prosperity Initiative Toolkit. World Urban Campaign Secretariat.

UN-Habitat. 2015a. The City Prosperity Initiative: 2015 Global City Report. International City Leaders.

UN-Habitat. 2015b. Urban Planning and Design at UN-Habitat. United Nations Human Settlements Programme (UNHSP).

UN-Habitat. 2016a. The City Prosperity Initiative. United Nations Human Settlements Programme (UNHSP).

UN-Habitat. 2016b. Measurement of City Prosperity: Methodology and Metadata. United Nations Human Settlements Programme (UNHSP).

UN-Habitat. 2016c. City Prosperity Initiative - Metropolitan Cities. International City Leaders.

Wong, Cecilia. 2015. "A Framework for 'City Prosperity Index': Linking Indicators, Analysis and Policy.” Habitat International 45: 3-9. 